\title{
Conversion of hydroxycinnamic acids into volatile phenols in a synthetic medium and in red wine by Dekkera bruxellensis
}

\author{
Transformação de ácidos hidroxicinâmicos em fenóis voláteis em meio sintético e em vinho tinto \\ por Dekkera bruxellensis
}

\author{
Maria João CABRITA ${ }^{1,2 *}$, Vera PALMA ${ }^{1}$, Raquel PATÃO ${ }^{1}$, Ana Maria Costa FREITAS ${ }^{1,2}$
}

\begin{abstract}
The conversion of $p$-coumaric acid, ferulic acid, and caffeic acid into 4-ethylphenol, 4-ethylguaiacol and 4-ethylcatechol was studied in Dekkera bruxellensis ISA 1791 under defined conditions in a synthetic medium and in a red wine. Liquid chromatography (HPLC-DAD) was used to quantify the phenolic acids, and gas chromatography (GC) coupled to a FID detector was used to quantify volatile phenols using a novel analytical methodology that does not require sample derivatization. Identification was achieved by gas chromatography-mass detection (GC-MS). The results show that phenolic acids concentration decreases while volatile phenols concentration increases. The proportion of caffeic acid taken up by Dekkera bruxellensis is lower than that for p-coumaric or ferulic acid; therefore less 4-ethylcatechol is formed. More important, 4-ethylcathecol synthesis by Dekkera bruxellensis in wine has never been demonstrated so far. These results contribute decisively to a better understanding of the origin of the volatile phenols in wines. The accumulation of these compounds in wine is nowadays regarded as one of the key factors of quality control.

Keywords: phenolic acids; volatile phenols; 4-ethylcatechol; red wine.
\end{abstract}

\section{Resumo}

A transformação do ácido p-cumárico, ácido ferúlico e ácido cafeico em 4-etilfenol, 4-etilguaiacol e 4-etilcatecol foi estudada na presença de Dekkera bruxelensis ISA 1791, sob condições controladas, em meio sintético e em vinho tinto. Os compostos fenólicos foram doseados por cromatografia em fase líquida (HPLC-DAD) e os fenóis voláteis foram doseados por cromatografia em fase gasosa (GC) com detector de ionização de chama (FID), recorrendo a uma metodologia que não requer prévia derivatização da amostra. A identificação dos compostos foi comprovada por espectrometria de massa (GC-MS). Os resultados demonstram que os teores em ácidos fenólicos diminuem enquanto se observa um aumento dos teores em fenóis voláteis. O ácido cafeico é dos três ácidos em estudo, o menos utilizado pela levedura, daí os teores em 4-etilcatecol serem os mais baixos observados. Esta síntese de 4-etilcatecol por Dekkeras bruxelensis em vinhos nunca tinha sido demonstrada. Os resultados obtidos contribuem, decisivamente, para um melhor conhecimento sobre a origem precisa dos fenóis voláteis nos vinhos. A acumulação destes compostos no vinho é,hoje em dia, considerada como um dos fatores-chave do controle de qualidade.

Palavras-chave: ácidos fenólicos; fenóis voláteis; 4-etilcatecol; vinho tinto.

\section{Introduction}

The accumulation of volatile phenols in wine has been a cause of great concern in modern enology being now a key point in the control of wine quality. Vinylphenols (4-vinylphenol and 4 vinylguaiacol) and ethylphenols (4-ethylphenol and 4-ehtylguaiacol) may be produced in wine, in a sequential pathway, due to microbial activity, imparting undesirable odours and flavours. The quality of wine is considered to be mainly affected by the accumulation of 4-ethylphenol and 4-ethylguaiacol, whose presence is commonly described as responsible for sensorial notes related to "leather", "horse sweat", "animal", and "medicinal".

The precise origin(s) of volatile phenols has been under discussion for some time, but most likely they come from hydroxycinnamic acids or their corresponding tartaric esters.
The production of these compounds has been recognised as an important characteristic of the yeast Brettanomyces/Dekkera (LOUREIRO; MALFEITO-FERREIRA, 2006).

A number of microbial species have been reported as able to decarboxylate hydroxycinnamic acids, such as ferulic, $p$-coumaric, and caffeic acids. The products of these decarboxylations are ethylphenols that give rise to strong smoky and aromatic odours and flavours, and are regarded as the source of phenolic off-flavours in several beers and wines (EDLIN et al., 1998). These off-flavours, described as the phenolic character, can appear in all red wines at different stages during production and ageing processes.

The metabolism of hydroxycinnamic acids by Brettanomyces/ Dekkera yeasts is due to a sequential action of two enzymes: a

Received 9/7/2010

Accepted 14/11/2011 (004917)

${ }^{1}$ Departamento de Fitotecnia, Laboratório de Enologia, Escola de Ciências e Tecnologia da Universidade de Évora, Ap 94, 7002-554, Évora, Portugal, e-mail: mjbc@uevora.pt

${ }^{2}$ Instituto de Ciências Agrárias e Ambientais Mediterrânicas - ICAAM, Portugal

${ }^{*}$ Corresponding author 
cinnamate decarboxylase, which cleaves the phenolic acid (namely ferulic, caffeic, and $p$-coumaric acids) directly into the corresponding vinylphenol and a vinylphenol reductase, which converts the vinyl into the corresponding ethylphenol (CHATONNET; DUBOURDIEU; BOIDRON, 1995; EDLIN et al., 1995). Benito et al. (2009) studied possible ways of controlling these organisms in wineries by studying several factors affecting the enzymatic activity of Dekkeras/ Brettanomyces. D. bruxellensis shows hydroxycinnamate decarboxylase and vinyl reductase activity under oenological conditions to such an extent that the species is considered an undesirable yeast capable of producing high concentrations of 4-ethylphenol (SUÁREZ et al., 2007). Recently, Godoy et al. (2008) have shown the presence of a p-coumarate decarboxylase (CD) and a Vinylphenol Reductase (VR) in B. bruxellensis. The authors demonstrated that both enzymatic activities were stable at $\mathrm{pH} 3.4$, but in the presence of ethanol the $\mathrm{CD}$ activity decreased drastically while the VR activity was more stable.

D. bruxellensis is nowadays considered to be the main cause of wine spoilage, especially of fashionable premium red wines matured in oak casks, and can be responsible for serious economic losses (SUÁREZ et al., 2007; LOUREIRO; MALFEITO-FERREIRA, 2003).

Several studies report the finding of 4-ethylphenol and 4-ethylguaiacol in wines (PIZARRO; PÉREZ-DEL-NOTARIO; GONZÁLEZ-SÁIZ, 2007; VALENTÃO et al., 2007). The presence of 4-ethylcatechol, on the other hand, has been reported only once, by Hesford et al. (2004), until Carrillo and Tena (2007) reported the presence of 4-ethylcatechol in some wines affected by Brettanomyces. More recently Larcher et al. (2008) developed a HPLC-CEAD method for quantification of 4-ethylcatechol and applied it to Italian wines.

The aim of this work was to evaluate the disappearance of cinnamic acids and consequent appearance of volatile phenols by a strain of $D$. bruxellensis with emphasis on 4-ethylcatechol using a very simple sample preparation method. The present study was carried on in a model solution as well as in a red wine.

\section{Material and methods}

\subsection{Yeast strain and inocula preparation}

D. bruxellensis ISA 1791 strain was isolated from a phenolic tainted red wine (RODRIGUES et al., 2001) and kept in GYPC medium (20 g. L $^{-1}$ glucose (Merck, Darmstadt, Germany), 3 g.L. $L^{-1}$ yeast extract (Difco Laboratories, Detroit, USA), 5 g.L. ${ }^{-1}$ peptone (Difco), and 20 g.L. $\mathrm{L}^{-1}$ agar, $\mathrm{pH}$ 6.0, 5 g.L. $\mathrm{L}^{-1}$ of calcium carbonate (Merck), at $4{ }^{\circ} \mathrm{C}$.

A synthetic medium (6.7 g.L $\mathrm{L}^{-1}$ YNB (Difco); $2 \%(\mathrm{w} / \mathrm{v})$ glucose, $10 \%(\mathrm{v} / \mathrm{v}$ ) ethanol, $\mathrm{pH} 3.5)$, filtered by $0.22 \mu \mathrm{m}$ sterilized membranes filters was used to grow the yeast strain. Stirring was applied at $120 \mathrm{rpm}$, and temperature was kept at $25^{\circ} \mathrm{C}$. Biomass concentration was followed everyday by optical density measurements at $640 \mathrm{~nm}$. When biomass reached $\mathrm{OD}_{640 \mathrm{~nm}}=1$, the liquid medium was divided into $12(500 \mathrm{~mL})$ flasks (samples $\mathrm{B} 1$ to B12). Each flask received $10^{4}$ cell. $\mathrm{mL}^{-1}$.

\subsection{Samples}

\section{Case 1. Synthetic medium}

$10 \mathrm{mg} \cdot \mathrm{L}^{-1}$ of caffeic acid were added to samples B1, B2, and B3; $10 \mathrm{mg} . \mathrm{L}^{-1}$ of $p$-coumaric acid were added to samples B4, B5, and B6; and $10 \mathrm{mg} \cdot \mathrm{L}^{-1}$ of ferulic acid were added to samples B7, B8, and B9. Samples B10, B11, and B12 were added 10 mg.L $\mathrm{L}^{-1}$ of each acid (30 mg. $\mathrm{L}^{-1}$ total amount). All samples were kept at $25^{\circ} \mathrm{C}$ under anaerobic conditions.

$50 \mathrm{~mL}$ of each sample were collected at days $0,2,4,6$, and 8 for HPLC and GC analysis.

\section{Case 2. Wine inoculated with same yeast strain}

A young red wine from 2007 vintage, collected after alcoholic fermentation and prior to malolactic fermentation, was divided in two parts: one was the control $(\mathrm{C})$ and the other was inoculated with $D$. bruxellensis ISA 1791 strain $(\mathrm{Y})$. To half of wines $\mathrm{C}$ and $\mathrm{Y}, 10 \mathrm{mg} \cdot \mathrm{L}^{-1}$ of each phenolic acid $(\mathrm{C}+\mathrm{A}$ and $\mathrm{Y}+\mathrm{A}$ ) were added. The wines were kept at $25^{\circ} \mathrm{C}$ under anaerobic condition and samples were collected after one and two months. The experiment was performed in triplicate.

\section{Case 3. Naturally contaminated wine}

A red wine from Trincadeira variety fully described in a previous study (CABRITA et al., 2008) aged in a $20 \mathrm{~L}$ glass container and developed a strong "horse" flavour, indicating a possible contamination with $D$. bruxellensis. Samples were collected and phenolic compounds and volatile phenols were analysed.

\subsection{Reagents and standards}

Water was previously purified in a Mili-Q system (Millipore, Bedford, MA, USA). HPLC grade methanol, n-pentane, ethanol, and anhydrous sodium sulphate were from MercK (Darmstadt, Germany). Analytical grade diethyl ether was from Lab-Scan Analytical Sciences (Dublin, Ireland).

Ferulic acid was supplied by Extrasynthese (Genay, France). Caffeic acid and $p$-coumaric acid from Sigma-Aldrich (St Louis, MO). 4-ethylphenol, 4-ethylcatechol, 4-ethylguaiacol and 3,4-dimethylphenol were supplied respectively from Merck, ABCR (GmbH\&Co), TCI (Tokyo Casei), and Sigma-Aldrich (St Louis, MO).

\subsection{HPLC analysis}

\section{Sample preparation}

The samples were extracted by liquid-liquid extraction using diethyl ether: $5 \mathrm{~mL}$ of wine with $\mathrm{pH}$ adjusted to 2 were extracted twice with $5 \mathrm{~mL}$ of diethyl ether for ten minutes. The organic phase was dried over $\mathrm{Na}_{2} \mathrm{SO}_{4}$; the solvent was evaporated under nitrogen; the dry residue obtained was dissolved in methanol-water $(1: 1, \mathrm{v} / \mathrm{v})$ and filtered through a $0.45 \mu \mathrm{m}$ Nylaflo membrane filter (Gelman) before being injected into 
the chromatograph. $20 \mu \mathrm{L}$ of each extract were used for HPLC analysis.

\section{Chromatographic conditions}

The column used was a Superpher 100, C18 (5 $\mu$ m packing, $250 \times 4.6 \mathrm{~mm}$ i.d.) (Merck, Germany) installed into aHewllet Packard 1050 equipment, and a Hewllet Packard Diode Array 1100 detector (Agilent Tecnhologies, Germany), was used. Flow rate was $1 \mathrm{~mL} /$ minute. The mobile phase was solvent A: water:acetic acid $(98: 2, \mathrm{v} / \mathrm{v})$ and solvent B: water:methanol:acetic acid $(68: 30: 2, \mathrm{v} / \mathrm{v})$. A gradient program was adopted as follows for solvent A: from 95 to $70 \%$ (12 minutes); from 70 to $45 \%$ (15 minutes); from 45 to $23 \%$ (6 minutes); isocratic for 9 minutes; from 23 to $5 \%$ ( 5 minutes); from 5 to $0 \%$ ( 3 minutes); isocratic for 5 minutes, and a post-run of 5 minutes for re-equilibration of the initial gradient. The detection wavelength used was $320 \mathrm{~nm}$. The sample preparation and chromatographic conditions were fully described in a previous study (CABRITA et al., 2008).

\section{Calibration curves}

A stock solution containing caffeic, ferulic, and p-coumaric acids was prepared in ethanol $12 \%(\mathrm{v} / \mathrm{v})$. Six working solutions with concentration between $0.39-50.0 \mathrm{mg} . \mathrm{L}^{-1}$ of cafeic and p-cumaric acids and between 0.78-50.0 mg. $\mathrm{L}^{-1}$ of ferulic acid were extracted as described above. Each standard was injected three times. Calibration parameters are presented in Table 1.

\subsection{GC analysis}

\section{Sample preparation}

To $10 \mathrm{~mL}$ of each sample, $200 \mu \mathrm{L}$ of internal standard (3,4-dimetylphenol $800 \mathrm{mg} \cdot \mathrm{L}^{-1}$ ) were added. The samples were extracted twice using $5 \mathrm{~mL}$ of diethyl ether/pentane (1:1) for 10 minutes. The organic phases were collected, dried over $\mathrm{Na}_{2} \mathrm{SO}_{4}$, and the solvent evaporated under a gentle stream of nitrogen until approximately $0.5 \mathrm{~mL}$, prior to injection.

\section{Chromatographic conditions}

A GC-FID HP 6890 (Agilent Tecnhologies, Germany) series with a RTX-Wax column from Restek
$(30 \mathrm{~m} \times 0.25 \mathrm{~mm} \times 0.25 \mu \mathrm{m})$ was used. The injector, in splitless mode, at $230^{\circ} \mathrm{C}$, the injection volume was $1 \mu \mathrm{L}$, and the detector temperature was $250^{\circ} \mathrm{C}$. Helium was used as carrier gas at a flow of $1.4 \mathrm{~mL} /$ minutes. The oven was initially set at $80^{\circ} \mathrm{C}$, raised to $140{ }^{\circ} \mathrm{C}$ at $10^{\circ} \mathrm{C} /$ minutes, to $155^{\circ} \mathrm{C}$ at $5^{\circ} \mathrm{C} /$ minutes, to 200 at $10^{\circ} \mathrm{C}$ (held for 2 minutes), and finally up to $220^{\circ} \mathrm{C}$ at a rate of $20^{\circ} \mathrm{C} /$ minutes.

\section{Calibration curves}

The internal standard was prepared in ethanol $75 \%(\mathrm{v} / \mathrm{v})$. A stock solution containing $80 \mathrm{mg}$ of 4-ethylcatechol, $80 \mathrm{mg}$ of 4-ethylguaiacol, and $50 \mathrm{mg}$ of 4-ethylphenol was prepared in ethanol $75 \%(\mathrm{v} / \mathrm{v})$. The working solutions were prepared by diluting the stock solution with a model solution (4 g. $\mathrm{L}^{-1}$ tartaric acid; 3 g.L. $\mathrm{L}^{-1}$ malic acid; 0.1 g.L. $\mathrm{L}^{-1}$ acetic acid; 0.025 g.L. $\mathrm{L}^{-1}$ magnesium sulphate; 0.1 g.L. $\mathrm{L}^{-1}$ potassium sulphate and 90 g.L. $\mathrm{L}^{-1}$ ethanol; $\mathrm{pH}=3.30$ ). Final concentrations of $0.24,0.50,1,2,4$, 8 , and $16 \mathrm{mg} \cdot \mathrm{L}^{-1}$ were obtained. Each standard was injected three times. The LOD and LOQ limits were established using calibration data and regression statistics considering the $y$-intercept and standard deviation of the regression according to Miller and Miller (1993). Calibration parameters are presented in Table 2.

\subsection{GCMS analysis}

A GC HP 5890 series II coupled to a HP 5972 series mass selective detector (Agilent Tecnhologies, Germany), equipped with a column HP-5HS from Agilent Technologies Inc. $(30 \mathrm{~m} \times 0.25 \mathrm{~mm} \times 0.25 \mu \mathrm{m})$, was used for 4-ethylcatechol identification.

The injector in splitless mode was at $250^{\circ} \mathrm{C}$, injection volume of $1 \mu \mathrm{L}$, delay was 3 minutes, and helium flow rate was at $1 \mathrm{~mL} /$ minute. The oven was programmed from 80 to $200{ }^{\circ} \mathrm{C}$ at $8{ }^{\circ} \mathrm{C} /$ minutes. Transfer line was $280^{\circ} \mathrm{C}$. Electron Impact (EI) ionization mode at $70 \mathrm{eV}$ was used; Spectra were recorded in Selective Ion Monitoring mode (SIM). Mass spectral data and retention times were determined for standard compounds. The ions monitored were as follows: 4-ethylcatechol, $\mathrm{m} / \mathrm{z}$ $123+138$, 4-ethylguaiacol, $\mathrm{m} / \mathrm{z} 137+152$, 4-ethylphenol, and 3,4-dimethylphenol, m/z $107+122$.

Table 1. Parameters for the calibration of phenolic acids.

\begin{tabular}{lccccc}
\hline Compounds & RT \pm SD (minutes) & Equation & $\mathrm{r}^{2}$ & LOD $\left(\mathrm{mg} . \mathrm{L}^{-1}\right)$ & LOQ $\left(\mathrm{mg} . \mathrm{L}^{-1}\right)$ \\
\hline Caffeic acid & $27.20 \pm 0.98$ & $\mathrm{y}=391.03 \mathrm{x}-167.74$ & 0.9993 & 1.34 & 4.47 \\
$p$-Coumaric acid & $37.68 \pm 1.05$ & $\mathrm{y}=521.08 \mathrm{x}-107.10$ & 0.9999 & 0.58 & 1.94 \\
Ferulic acid & $43.94 \pm 1.40$ & $\mathrm{y}=421.86 \mathrm{x}-276.27$ & 0.9986 & 2.01 & 6.70 \\
\hline
\end{tabular}

$\mathrm{RT} \pm$ S.D. retention time \pm estimated standard deviation $(\mathrm{n}=3) ; \mathrm{r}^{2}$ determination coefficient. LOD limit of detection, LOQ limit of quantification.

Table 2. Parameters for the calibration of volatile phenols.

\begin{tabular}{cccccc}
\hline Compounds & $\mathrm{RT} \pm \mathrm{SD}$ (minutes) & Equation & $\mathrm{r}^{2}$ & $\mathrm{LOD}\left(\mathrm{mg} . \mathrm{L}^{-1}\right)$ & $\mathrm{LOQ}\left(\mathrm{mg} \cdot \mathrm{L}^{-1}\right)$ \\
\hline 4-ethylguaiacol & $6.68 \pm 0.01$ & $\mathrm{y}=0.0504 \mathrm{x}+0.0054$ & 0.9993 & 0.031 & 0.091 \\
4-ethylphenol & $8.01 \pm 0.01$ & $\mathrm{y}=0.0611 \mathrm{x}-0.0083$ & 0.9999 & 0.015 & 0.029 \\
4-ethylcatechol & $14.67 \pm 0.05$ & $\mathrm{y}=0.0376 \mathrm{x}-0.0004$ & 0.9993 & 0.019 & 0.065 \\
\hline
\end{tabular}

$\mathrm{RT} \pm$ S.D. retention time \pm estimated standard deviation $(n=3) ; \mathrm{r}^{2}$ determination coefficient. LOD limit of detection, LOQ limit of quantification. 


\subsection{Statistical analysis}

The evaluation of statistical significance was determined by ANOVA, followed by Fisher-LSD test using SPSS 7.0 software. The level of significance was set at $\mathrm{p}<0.05$.

\section{Results and discussion}

\section{Case 1. Synthetic medium}

Table 3 presents the results obtained for the quantification of phenolic acids and volatile phenols in the studied samples. It is clear that phenolic acids concentration decrease with time, while volatile phenols concentration increases. 4-ethylcatechol is the last one to appear, and it is the least significant.

Both 4-ethylphenol and 4-ethylguaiacol where detected at day 2 after yeast inoculation and reached concentration of 7.69 and $7.25 \mathrm{mg} . \mathrm{L}^{-1}$ at day 8 , while the content of their precursor ( $p$-coumaric and ferulic acids) decreased up to 0.28 and $0.72 \mathrm{mg} . \mathrm{L}^{-1}$ at the same day.

Due to vicinal $\mathrm{OH}$ groups, 4-ethylcatechol is thermally unstable at the required analysis temperature; moreover it can also react with most of the commercial available stationary phases used for GC columns. Detection and quantification is usually observed only after chemical derivatization (LARCHER et al., 2008).

4-ethylcatechol was detected four days after yeast inoculation, and the analysis was performed without chemical derivatization. The final amount detected reached $1.24 \mathrm{mg} . \mathrm{L}^{-1}$ (at day 8), while caffeic acid (the precursor) concentration decreased up to $5.51 \mathrm{mg} \cdot \mathrm{L}^{-1}$.

Conversion rate of hydroxycinnamic acids into volatile phenols in a synthetic medium (Table 4) was obtained through the ratio of the maximum concentration obtained for volatile phenols and the theoretical concentration obtained from $10 \mathrm{mg} . \mathrm{L}^{-1}$ of hydroxycinamic acids.

Conversion rates greater than $90 \%$ were obtained for the conversion of $p$-coumaric acid into 4-ethylphenol and from ferulic acid into 4-ethylguaiacol, but a rate smaller than $20 \%$ was found for the conversion of caffeic acid into 4-ethylcathecol. These results may justify why only recently the presence of 4-ethylcatechol in wines was reported (HESFORD et al., 2004). Although caffeic acid is present in wines in considerable amounts and has a structure similar to the other phenolic acids, these results seem to indicate that $p$-coumaric and ferulic acids are easily used by yeast metabolism.
A difference between the initial concentration, $10 \mathrm{mg} \cdot \mathrm{L}^{-1}$ of caffeic, ferulic and $p$-coumaric acids, and the concentration detected by HPLC, immediately after yeast inoculation, was observed (samples B1 to B9). Similar results were described by other authors (MEDAWAR, 2003; SALAMEH et al., 2008). The lost of the hydroxycinamic acids in a synthetic medium might be explained either by their instability at high temperature, by esterification reaction with ethanol, or by the ability of yeast cell walls to adsorb these compounds. Salameh et al. (2008) showed that although $p$-coumaric acid was stable at oenological temperatures, it can, like polyphenols, react with ethanol, and it can also be adsorbed into Brettanomyces yeast.

The results regarding the samples in which the three acids were added simultaneously (B10 to B12) are presented in Table 5. When compared with the results obtained in previous samples (B1 to B9), no clear differences could be observed. Yeast strain seems to have similar behaviour either in the presence of only one acid or in the presence of the three acids together. A preferential use of a single acid was not observed either.

\section{Case 2. Wine inoculated with same yeast strain and added $10 \mathrm{mg} . \mathrm{L}^{-1}$ of each phenolic acid}

The results from this assay are shown in Table 6. In wine samples without yeast inoculation, the content of hydroxycinnamic acids increased with time; probably due to the hydrolysis of hydroxycinnamic esters. The presence of volatile phenols was slightly detected, more likely due to lactic bacteria activity, which also has the ability to convert vinyl phenols into ethyl phenols.

In wine samples inoculated with $D$. bruxellensis, a clear decrease in the $p$-coumaric and ferulic acids content as well as an increase in the corresponding volatile phenols could be observed. This result was clearer in samples to which acids were added. One month after inoculation, the content of hydroxycinnamic acids where near the added amounts (10 mg. $\left.\mathrm{L}^{-1}\right)$.

Table 4. Conversion rate of hydroxycinnamic acids into volatile phenols in synthetic medium.

\begin{tabular}{lccr}
\hline \multicolumn{1}{c}{ Compound } & $\begin{array}{c}\text { Obtained } \\
\text { concentration } \\
\left(\mathrm{mg} . \mathrm{L}^{-1}\right)\end{array}$ & $\begin{array}{c}\text { Theoretical } \\
\text { concentration } \\
\left(\mathrm{mg} . \mathrm{L}^{-1}\right)\end{array}$ & $\begin{array}{c}\text { Conversion } \\
\text { rate }(\%)\end{array}$ \\
\hline 4-ethylguaiacol & $7.25 \pm 0,53$ & 7.84 & 92.47 \\
4-ethylphenol & $7.69 \pm 0.36$ & 7.44 & 103.36 \\
4-ethylcatechol & $1.24 \pm 0.34$ & 7.66 & 16.19 \\
\hline
\end{tabular}

Table 3. Phenolic acids and volatile phenols (mg. $\left.\mathrm{L}^{-1}\right)$ in samples B1 to B9.

\begin{tabular}{|c|c|c|c|c|c|c|}
\hline Day & Caffeíc acid & $p$-coumaric acid & Ferulic acid & 4-ethylguaiacol & 4-ethylphenol & 4-ethylcatechol \\
\hline 0 & $7.13 \pm 0.49^{a}$ & $3.80 \pm 0.66^{\mathrm{a}}$ & $2.56 \pm 0.35^{\mathrm{a}}$ & nd & nd & nd \\
\hline 2 & $8.61 \pm 0.58^{\mathrm{a}}$ & $2.10 \pm 0.59^{b}$ & $2.90 \pm 0.24^{\mathrm{a}}$ & $4.56 \pm 0.42^{\mathrm{a}}$ & $3.67 \pm 0.83^{\mathrm{a}}$ & nd \\
\hline 4 & $7.67 \pm 0.60^{\mathrm{a}}$ & $0.97 \pm 0.22^{c}$ & $1.40 \pm 0.11^{\mathrm{b}}$ & $6.50 \pm 0.75^{\mathrm{b}}$ & $6.09 \pm 0.54^{\mathrm{b}}$ & $0.13 \pm 0.03^{\mathrm{a}}$ \\
\hline 6 & $5.80 \pm 1.25^{\mathrm{b}}$ & $0.36 \pm 0.06^{\mathrm{d}}$ & $0.89 \pm 0.07^{c}$ & $7.35 \pm 0.79^{b}$ & $7.28 \pm 0.42^{\mathrm{b}}$ & $0.52 \pm 0.11^{\mathrm{b}}$ \\
\hline 8 & $5.51 \pm 0.64^{b}$ & $0.28 \pm 0.01^{\mathrm{d}}$ & $0.72 \pm 0.07^{c}$ & $7.25 \pm 0.53^{b}$ & $7.69 \pm 0.36^{b}$ & $1.24 \pm 0.34^{c}$ \\
\hline
\end{tabular}

Different letters in a row denote a significant difference with $95 \%$ confidence level in the Fisher's LSD multiple comparison test. nd - not detected. 
Table 5. Phenolic acids and volatile phenols (mg. $\left.\mathrm{L}^{-1}\right)$ in samples B10-B12.

\begin{tabular}{ccccccc}
\hline Day & Caffeic acid & $p$-coumaric acid & Ferulic acid & 4-ethylguaiacol & 4-ethylphenol & 4-ethylcatechol \\
\hline 0 & $7.24 \pm 0.36^{\mathrm{a}}$ & $6.78 \pm 0.50^{\mathrm{a}}$ & $4.87 \pm 0.38^{\mathrm{a}}$ & $\mathrm{Nd}$ & $\mathrm{Nd}$ & $\mathrm{Nd}$ \\
2 & $9.26 \pm 1.66^{\mathrm{b}}$ & $3.32 \pm 0.98^{\mathrm{b}}$ & $3.24 \pm 0.60$ & $5.18 \pm 0.21^{\mathrm{a}}$ & $3.38 \pm 0.13^{\mathrm{a}}$ & $\mathrm{Nd}$ \\
4 & $6.77 \pm 0.84^{\mathrm{a}}$ & $1.67 \pm 0.18^{\mathrm{c}}$ & $1.35 \pm 0.26^{\mathrm{c}}$ & $7.36 \pm 0.42^{\mathrm{b}}$ & $5.94 \pm 0.14^{\mathrm{b}}$ & $0.46 \pm 0.05^{\mathrm{a}}$ \\
6 & $6.22 \pm 0.39^{\mathrm{a}}$ & $0.62 \pm 0.03^{\mathrm{d}}$ & $0.58 \pm 0.08^{\mathrm{d}}$ & $8.41 \pm 0.16^{\mathrm{b}}$ & $7.00 \pm 0.13^{\mathrm{c}}$ & $0.99 \pm 0.36^{\mathrm{b}}$ \\
8 & $4.71 \pm 0.31^{\mathrm{c}}$ & $0.58 \pm 0.09^{\mathrm{d}}$ & $0.53 \pm 0.02^{\mathrm{d}}$ & $8.37 \pm 0.47^{\mathrm{b}}$ & $7.17 \pm 0.21^{\mathrm{c}}$ & $1.89 \pm 0.18^{\mathrm{c}}$ \\
\hline
\end{tabular}

Different letters in a row denote a significant difference with $95 \%$ confidence level in the Fisher's LSD multiple comparison test. nd - not detected.

Table 6. Phenolic acids and volatile phenols $\left(\mathrm{mg} \cdot \mathrm{L}^{-1}\right)$ in wine contaminated with yeast inoculation.

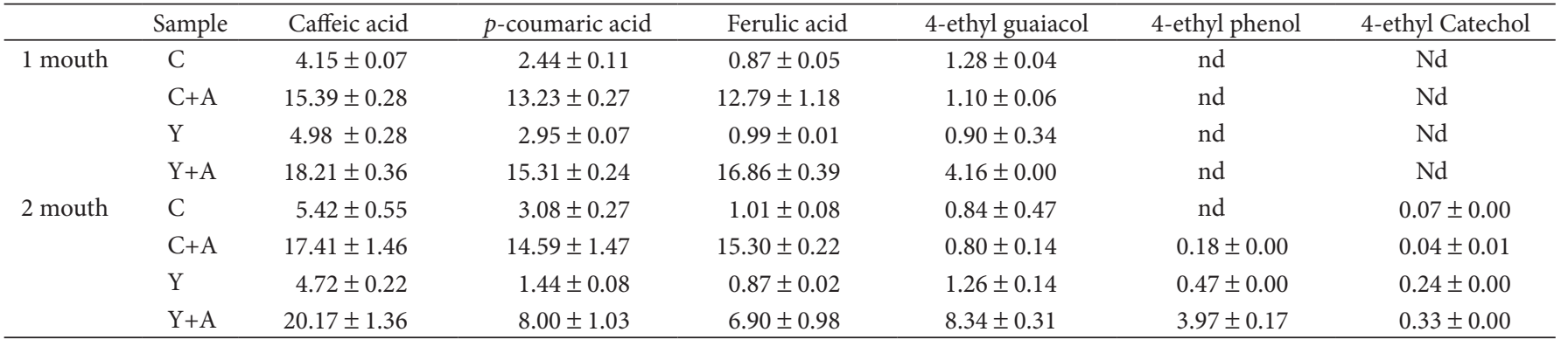

C - control, Y - yeast; A - acids; nd - not detected.

Table 7. Phenolic acids and volatile phenols $\left(\mathrm{mg} \cdot \mathrm{L}^{-1}\right)$ in wine naturally contaminated.

\begin{tabular}{cccccc}
\hline Caffeíc acid & $p$-coumaric acid & Ferulic acid & 4-ethylguaiacol & 4-ethylphenol & 4-ethylcatechol \\
\hline $13.12 \pm 0.39$ & $3.00 \pm 0.30$ & $1.01 \pm 0.12$ & $1.44 \pm 0.20$ & $2.24 \pm 0.12$ & $0.96 \pm 0.36$ \\
\hline
\end{tabular}

By that time, 4-ethylguaiacol was the only volatile phenol whose presence was detected. Although degradation occurred slower than in synthetic medium, after two months the $p$-coumaric and ferulic acids contents were half the initial concentration and all three volatile phenols were detected. 4-ethylguaiacol presented the highest concentration (8.34 mg. $\left.\mathrm{L}^{-1}\right)$.

The observed decrease of the ferulic acid content is not in accordance with previous reported results. Silva et al. (2005) argue that although ferulic acid is also a precursor of volatile phenols, no decrease of its content was observed in inoculated samples of Dao red wine with various strains of D. bruxellensis.

\section{Case 3. Naturally contaminated wine}

After two years in $20 \mathrm{~L}$ glass carboyl, a red wine previously described (CABRITA et al., 2008) developed a strong "horse" smell. Table 7 shows the phenolic acids and the amounts of volatile phenols for this wine.

The presence of 4-ethylcatechol in wine samples, without prior derivatization was confirmed by GC-MS analysis.

A higher value was found for 4-ethylphenol (2.24 mg.L.-1), followed by 4 -ethylguaicol (1.44 mg.L $\left.\mathrm{L}^{-1}\right)$. 4-ethylcatechol (0.96 mg.L $\left.\mathrm{L}^{-1}\right)$ presented the smallest amount. Values obtained for 4-ethylphenol and 4-ethylguaiacol are higher than the reported sensory perception thresholds for 4-ethylphenol and 4-ethylguaiacol alone in a red wine (605 and $100 \mu \mathrm{g} . \mathrm{L}^{-1}$, respectively) (CHATONNET et al., 1992), and thus in accordance with the strong horse smell detected. The values obtained in this study are within the limits detected and reported by several authors for red wines produced and stored under different conditions (CHATONNET et al., 1992; POLLNITZ; PARDON; SEFTON, 2000a,b).

During aging, wines phenolic acids content increases from an average value of 10.24 to $17.13 \mathrm{mg} . \mathrm{L}^{-1}$ due to caffeic acid (data not show) transformation/degradadtion. It has been stated that storage conditions may affect wine phenolic content since they can induce hydrolysis, oxidation, and complexation reactions (ZAFRILLA et al., 2003). Hydrolysis, enzymatic or not, seems to be the major cause of free phenolic acids increase. Degradation by light or temperature (CHEYNIER; FULCRAND, 2003) has also been reported.

\section{Conclusions}

Bioconversion of hydroxycinamic acids into volatile phenols by Brettanonyces/Dekkera yeasts is a major problem in modern enology. The results obtained show that the D. bruxellensis strain used produces 4 -ethylphenol from $p$-coumaric acid, 4-ethylguaiacol from ferulic acid and 4-ethylcatechol from caffeic acid, either in synthetic medium or in a regular wine. All phenolic acids presented clear decreases in accordance with the increase in the corresponding volatile phenols. 4-ethylcathecol was analysed without derivatization. 


\section{Acknowledgement}

Authors wish to thank FCT (Fundação para a Ciência e a Tecnologia, Ministério da Ciência, Tecnologia e Ensino Superior) and POCI 2010 (Programa Operacional Ciência e Inovação 2010) for financial support (Projects POCI/AGR 56771 and POCI/AGR 55432). Authors also wish to thank Professor Malfeito-Ferreira and Professor Virgilio Loureiro (Instituto Superior de Agronomia, Lisboa, Portugal) for kindly providing the yeast strain as well as Prof. Pat Sandra (Richrom - Research Institute for Chromatography, Belgium) for the kind gift of the MS instrument used.

\section{References}

BENITO, S. et al. Factors affecting the hydroxycinnamate decarboxylase/ vinylphenol reductase activity of Dekkera/Brettanomyces: application for Dekkera/Brettanomyces control in red wine making. Journal of Food Science, v. 74, n. 1, p. 15-22, 2009. http://dx.doi. org/10.1111/j.1750-3841.2008.00977.x

CABRITA, M. J. et al. Impact of malolactic fermentation on low molecular weight phenolic compounds. Talanta, v. 74, p. 1281-1286, 2008. PMid:18371781. http://dx.doi.org/10.1016/j. talanta.2007.08.045

CARRILLO, J. D.; TENA, M. T. Determination of ethylphenols in wine by in situ derivatisation and headspace solid-phase microextractiongas chromatography-mass spectrometry. Annals of Bioanalytical Chemistry, v. 387, p. 2547-2558, 2007. PMid:17225107. http:// dx.doi.org/10.1007/s00216-006-1086-x

CHATONNET, P. et al. The origin of ethylphenols in wines. Journal of the Science and Food Agriculture, v. 60, n. 2, p. 165-178, 1992. http://dx.doi.org/10.1002/jsfa.2740600205

CHATONNET, P., DUBOURDIEU, D., BOIDRON, J. N. The influence of Brettanomyces/Dekkera sp. yeasts and lactic acid bacteria on the ethylphenol content of red wines. American Journal of Enology and Viticulture, v. 46, n. 4, p. 463-468, 1995.

CHEYNIER, V. F.; FULCRAND, H. Oxidación de los polifenoles en los mostos y los vinos. In: Flanzy, C. (Ed.). Enología: fundamentos científicos y tecnológicos. 2. ed. Madrid: Mundi-Prensa, 2003. p. 369-376.

EDLIN, D. A. N. et al. The biotransformation of simple phenolic compounds by Brettanomyces anomalus. FEMS Microbiology Letters, v. 125, n. 2-3, p. 311-316, 1995. http://dx.doi. org/10.1111/j.1574-6968.1995.tb07374.x

EDLIN, D. A. N. et al. Purification and characterization of hydroxycinnamate decarboxylase from Brettanomyces anomalus. Enzyme and Microbial Technology, v. 22, n. 4, p. 232-239, 1998. http://dx.doi.org/10.1016/S0141-0229(97)00169-5

GODOY, L. et al. Purification and characterization of a p-coumarate decarboxylase and a vinylphenol reductase from Brettanomyces bruxellensis. International Journal of Food Microbiology, v. 127, n.1-2, p. 6-11, 2008. PMid:18571756. http://dx.doi.org/10.1016/j. ijfoodmicro.2008.05.011

HESFORD, F. et al. Identification and analysis of 4-ethylcatechol in wines tainted by Brettanomyces. ASEV 55th annual meeting, San Diego, 2004
LARCHER, R. et al. Determination of 4-ethylcatechol in wine by high-performance liquid chromatography-coulometric electrochemical array detection. Analytica Chimica Acta, v. 609, n. 2, p. 235-240, 2008. PMid:18261519. http://dx.doi.org/10.1016/j. aca.2007.12.038

LOUREIRO, V.; MALFEITO-FERREIRA, M. Spoilage yeasts in the wine industry International Journal of Food Microbiology, v. 86, n.1-2, p. 23-50, 2003. http://dx.doi.org/10.1016/S01681605(03)00246-0

LOUREIRO, V.; MALFEITO-FERREIRA, M. Spoilage yeasts: Dekkeras/ Brettanomyces spp. In: BLACKBURN, C. (Ed.). Food spoilage microorganisms. Woodhead Publishing Limited: Cambridge, 2006. p. 354-398. http://dx.doi.org/10.1533/9781845691417.3.354

MEDAWAR, W. Etude physiologique et cinétique des levures du genre Brettanomyces dans un contexte oenologique. Institute polytechnique de Toulouse et Université Saint Joseph de Beyrouth, 2003.

MILLER, J. C.; MILLER, J. N. Statistics for analytical chemistry. 3. ed. Chichester: Ellis Horwood Editors, 1993.

PIZARRO, C.; PÉREZ-DEL-NOTARIO, N.; GONZÁLEZ-SÁIZ, J. M. Determination of Brett character responsible compounds in wines by using multiple headspace solid-phase microextraction. Journal of Chromatography A, v.1143, n.1-2, p.176-181, 2007. PMid:17210155. http://dx.doi.org/10.1016/j.chroma.2006.12.073

POLLNITZ, A. P.; PARDON, K. H.; SEFTON, M. A. 4-Ethylphenol, 4-ethylguaiacol, and oak lactones in Australian red wines. Australian Grapegrowth Winemaker, v. 438, p. 4552, 2000a.

POLLNITZ, A. P.; PARDON, K. H.; SEFTON, M. A. Quantitative analysis of 4-ethylphenol and 4-ethylguaiacol in red wine. Journal of Chromatography A., v. 874, n.1, p. 101-109, 2000b. http://dx.doi. org/10.1016/S0021-9673(00)00086-8

RODRIGUES, N. et al. Development and use of a differential medium to detect yeasts of the genera Dekkera/Brettanomyces. Journal of Applied Microbiology. v. 90, n. 4, p. 588-599, 2001. PMid:11309071. http://dx.doi.org/10.1046/j.1365-2672.2001.01275.x

SALAMEH, D. et al. Highlight on the problems generated by p-coumaric acid analysis in wine fermentations. Food Chemistry, v. 107, n. 4, p. 1661-1667, 2008. http://dx.doi.org/10.1016/j. foodchem.2007.09.052

SUÁREZ, R. et al. The production of ethylphenols in wine by yeasts of the genera brettanomyces and dekkera: a review. Food Chemistry, v.102, n.1, p.10-21, 2007. http://dx.doi.org/10.1016/j. foodchem.2006.03.030

SILVA, L. R. et al. Analysis of non-coloured phenolics in red wine: effect of Dekkera bruxellensis yeast. Food Chemistry, v. 89, n. 2, p. 185-189, 2005. http://dx.doi.org/10.1016/j.foodchem.2004.02.019

VALENTÃO, P. et al. Influence of Dekkera bruxellensis on the contents of anthocyanins, organic acids and volatile phenols of dão red wine. Food Chemistry, v.100, n.1, p. 64-70, 2007

ZAFRILLA, P. et al. Changes during storage in conventional and ecological wine: phenolic content and antioxidant activity. Journal of Agricultural and Food Chemistry, v. 51, n.16, p. 4694-4700, 2003. PMid:14705898. http://dx.doi.org/10.1021/jf021251p 